\title{
Validation of photograph series as a portion size measurement aid in dietary assessment in children
}

\author{
Ivana Rumbak ${ }^{1}$, Darja Sokolić ${ }^{2}$ Tena Blažok ${ }^{3}$, Dragica Šakić ${ }^{4}$, Diana Vukman ${ }^{5}$, \\ Tena Niseteo ${ }^{5}$, Irena Colić Barić ${ }^{1}$
}

Determining children's food consumption is challenging and requires dietetic methods that provide adequate specificity for describing, but also for quantifying food intake. To help survey respondents indicate food portion sizes, photograph series can be used, but these must be validated in a nationally representative sample of the population. The aim of the present study was to validate photograph series as a portion size measurement aid during dietary assessment of children in Croatia. This study involved 28 mothers of children aged 3 months to 10 years, who were asked to select one of four photographs in a series that best represented the quantity of food served to them. Of the 21 series tested, 17 were found to be appropriate for assessing food portion sizes. Participants were worst at assessing portion sizes of banana (29.3\%), porridge (22.8\%), hot dogs (20,3\%) and plain yoghurt (19.1\%). Further studies are needed to determine why these foods are poorly recognized so that photographs can be modified accordingly and validated.

Key words: FOOD; VALIDATION STUDIES; PORTION SIZE; CHILDREN

\section{INTRODUCTION}

Detailed, high-quality data on food consumption by individuals is of essential importance, especially among children. The methods and procedures of dietary studies in children have the goal of monitoring whether their nutritional intake is adequate, since energy and nutrients are needed to satisfy body's needs, as well as to support growth and tissue synthesis (1). Assessment of children's diet is particularly important in the light of the growing prevalence of obesity, which is not only a disease itself, but also a trigger for secondary complications and disorders (2). Such assessment can also serve as a screening method for the prevention of malnutrition in hospitalized children (3). This assessment is also valuable for assessing dietary risk from toxic ingredients, which pose an even greater risk to children than to adults because children consume larger amounts of food per kilogram of body weight.

Determining children's food consumption is challenging. Preschool children cannot remember or report their consumption, while school children are often unaware of the ingredients in the foods they eat or the preparation meth- ods used. This highlights the importance of applying the same dietary assessment methods across all age groups of children (4).

According to 2014 guidelines from the European Food Safety Authority, the most appropriate dietary assessment method for infants and children aged 3 months to 9 years is a food diary kept by a parent or guardian on two days at least one week apart (5). Several tools exist to help parents or guardians accurately report food portion sizes in dietary assessments of children, and there is no gold standard

\footnotetext{
'Laboratory of Nutrition Science, Faculty of Food Technology and Biotechnology, University of Zagreb, Zagreb, Croatia ${ }^{2}$ Croatian Food Agency, Osijek, Croatia ${ }^{3}$ student of Graduate Study Nutrition, Faculty of Food Technology and Biotechnology, University of Zagreb, Zagreb, Croatia ${ }^{4}$ Specialist Paediatric Office, Zagreb, Croatia

${ }^{5}$ Zagreb Children's Hospital, Zagreb, Croatia
}

\section{Correspondence to:}

Ivana Rumbak, Laboratory of Nutrition Science, Faculty of Food Technology and Biotechnology, University of Zagreb, Pierottijeva 6, HR-10000 Zagreb, Croatia, e-mail: ivana.rumbak@pbf.hr

Primljeno/Received: 21. 11. 2018., Prihvaćeno/Accepted:01. 2. 2019 

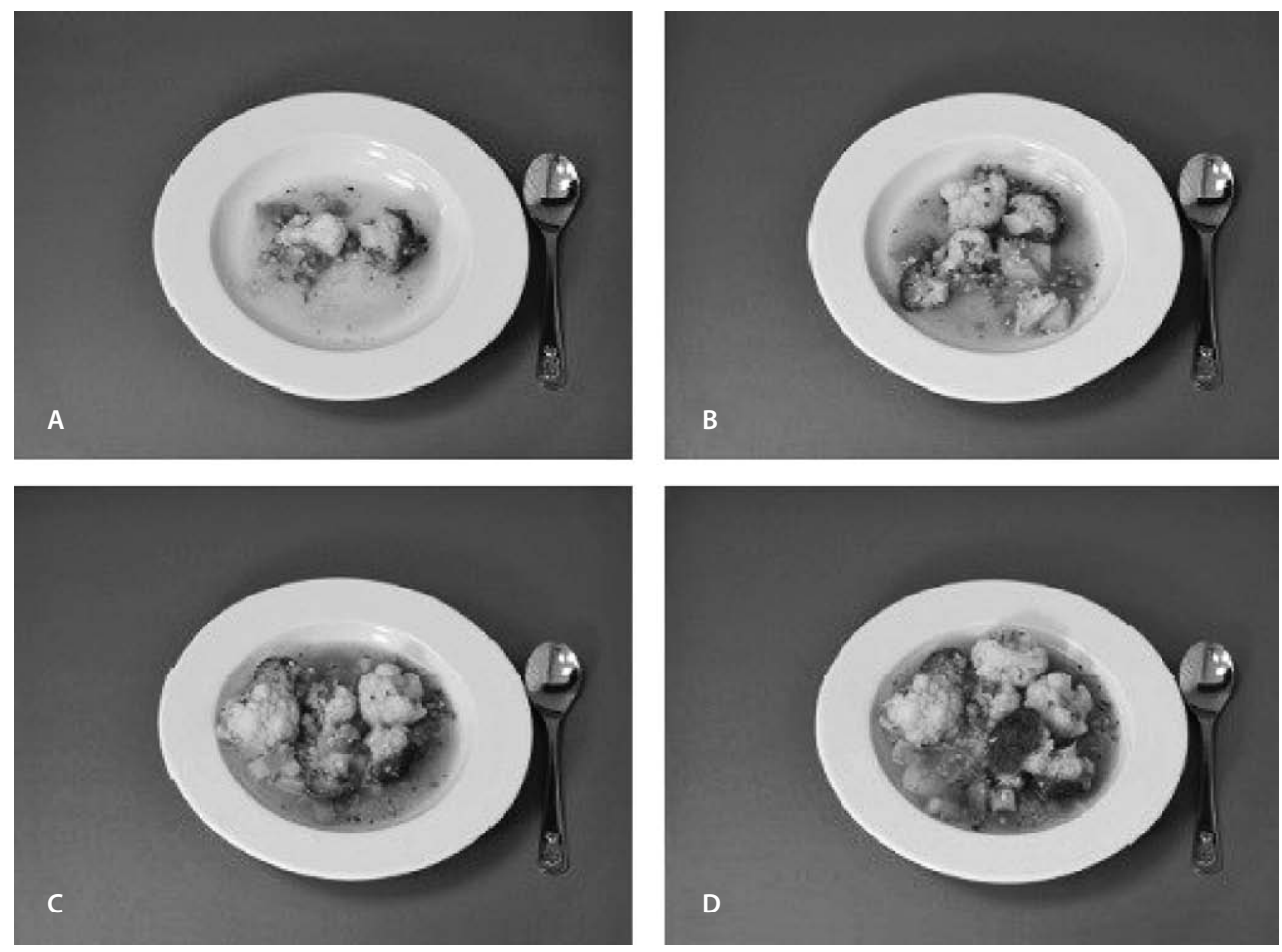

FIGURE 1. Example of a photograph series showing vegetable stew: (A) $60 \mathrm{~g}$, (B) $140 \mathrm{~g}$, (C) $220 \mathrm{~g}$, and (D) $300 \mathrm{~g}$.

widely accepted by most researchers. Among the more effective tools are photograph series depicting the relevant types of food in different portion sizes. In these photographs, the food is served on plates to allow the viewer to maintain the sense of proportion (6).

In a previous work, we developed photograph series depicting food and drink in different portion sizes for potential use in surveys of food consumption by toddlers in Croatia (7). That study demonstrated the need to validate the photographs with physical portions of food and drink; therefore, we undertook the present study.

\section{PARTICIPANTS AND METHODS}

\section{Participants}

This study was approved by the Ethics Committee of the Zagreb Children's Hospital and was carried out in accordance with the Helsinki Declaration. The participants in this study were 28 mothers of children aged 3 months to 10 years, who were identified through personal contacts and invited to enrol in the study by e-mail. The mothers were aged 29 to 46 years. They provided a written informed consent before enrolment. The consent form contained a short description of the research and its goals, and it mentioned that participation was voluntary and that participants could withdraw at any time.

\section{Selection, preparation and serving of food portions}

A total of 21 series of food photographs were analysed in this validation study: banana, chocolate, cereal flakes with chocolate, semolina porridge prepared with milk, hot dogs, apple, eggs, plain yoghurt, fruit yoghurt, meat soup, vegetable soup, cookies, bread, mandarin oranges, crepes, curved bread rolls (Croatian: kiflice), puffed corn chips (flips), pretzel sticks, ham, vegetable stew and fruit salad. Participants were asked to select the photograph from a series of four that best represented the portion of food served to them on a plate (Figure 1). Selected food was chosen based on the frequency of consumption determined in previous food picture series development study (7) and on the absence of similar portion size measurement aids for this specific population. The served food was not eaten.

The portion sizes of the food served on plates were predefined as follows: one portion was smaller than any of the four photographs; one portion was larger than any of the photographs; and one portion was equal to each one of the four photographs. The portions smaller and larger than those in the photographs were calibrated to be smaller or larger by one-third of the difference between the observed photograph and the next photograph in the series.

Foods were divided into two groups: 11 foods were assigned to the first group and 10 to the second group. The 12 portions of each food were randomly arranged on 12 tables. 


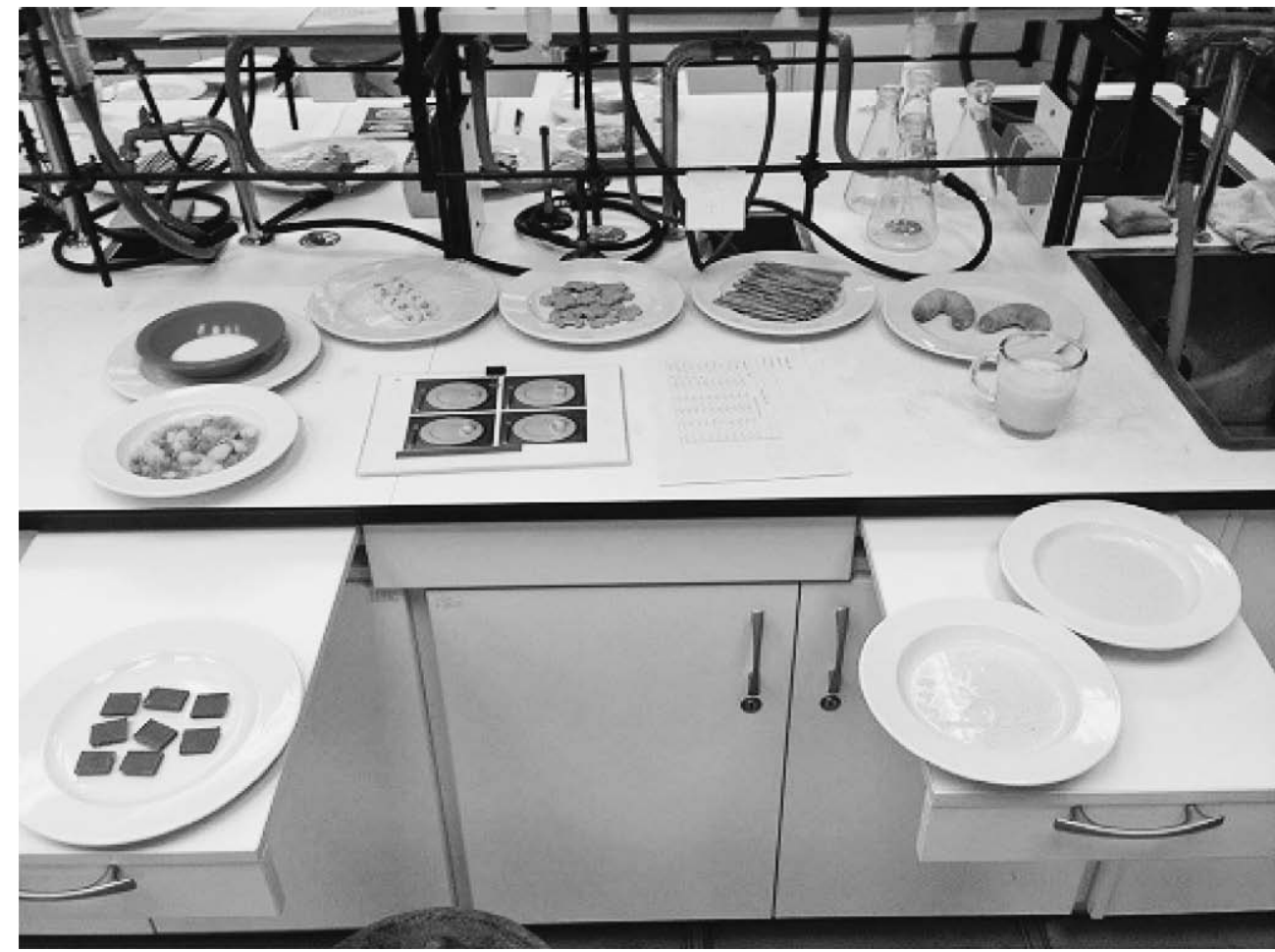

FIGURE 2. Image of one of the 12 tables where participants assessed real portion sizes using photographs.

The random.org on-line algorithm was used to distribute the portions of each food and to distribute the foods among the tables.

Foods were prepared in the kitchen of Zagreb Children's Hospital, weighed out using a kitchen scale (DKS-2055, Daewoo), and served on plates. The food was served in a way that visually resembled the corresponding photographs, and the plates were the same as those used to make the photographs (7) (Figure 1).

\section{Validation protocol}

The testing location was the Laboratory of Food Science, Faculty of Food Technology and Biotechnology, University of Zagreb. Participants were divided into the morning group and afternoon group, each with 12 tables. After the morning group had finished, the served food on all tables was rearranged. At each table, a book of photographs showing different portions of the food lay near the prepared food portions (Figure 2). The photograph series were encoded. Instructions for assessing food portions were located next to the photograph book. The study was designed so that each of the four photographs in each series was evaluated at least six times ( 3 portion sizes $\times 2$ participant groups).

Before assessing food portions, participants were asked to fill out a form containing questions about the individual's age, education level, as well as number and age of children. Then they were asked to circle which photograph in each series best represented the size of the real food portion served on a plate. The answer possibilities were to circle photographs A-D or "smaller than A", "between A and B", "between B and C", "between C and D" or "larger than D". Food portions were rated on 4- and 12-point scales. The 4-point scale corresponded to the portions in photographs A-D. On the 4-point scale, intermediate values (e.g., "-A" or "A+") were recorded as the main value (" $\mathrm{A}$ "). On the 12-point scale, all portion sizes including intermediate ones received separate ratings: a response of 1 indicated "smaller than $A$ ", 2 indicated "equal to A", 3 indicated "larger than A", and so on.

After assessment of food portions, participants were asked to fill out a qualitative evaluation of using photograph series for children's dietary assessment, using photographs to determine food portion sizes, and of the size of portions shown in the photographs relative to normal portions.

\section{Statistical methods}

Participant responses and food weight were analysed statistically using Spearman coefficients and the ANOVA $\omega^{2}$ test in SunCore software (KanDar Enterprises, Manchester, NH, USA). Data on percentages of evaluated food portions, percentages of participants, and subjective assessment of portion weights were analysed in Microsoft Excel 2010. 
The ANOVA $\omega^{2}$ provides a nonparametric coefficient that is not completely tied to the group of data. As a result, it can quantitatively describe the link between the dependent and independent variables without weighting either one excessively. Generally, $\omega^{2}$ values from 0 to 0.01 are taken to indicate weak correlation; 0.01 to 0.06 , intermediate correlation; 0.06 to 0.14 , significant difference; and >0.14, strong and significant difference. An advantage of the ANOVA $\omega^{2}$ test is that the coefficient also describes the magnitude of the difference between a participant's response and the real value. For example, $\omega^{2}=0.293$ indicates a difference of $29.3 \%$.

\section{RESULTS}

The largest proportion of participants (92.9\%) had more than 15 years of education (higher education). Just over half of the participants (51.4\%) had children aged 4-10 years, followed by those (43.2\%) with children aged $1-3$ years, and finally those (5.4\%) with children aged 3-11 months. Most participants (60.7\%) reported that they had never used photograph series to assess food portion sizes, while $21.4 \%$ reported that they had used photograph series for this purpose.

Smaller portions were correctly assessed more often. The rate of correct responses was largest for portion A (71.43\%) and smallest for portions C and D (57.14\%). Based on responses on the 4-point scale, the following foods were correctly assessed most often (Table 1): chocolate (100.00\%), apple (100.00\%), eggs (100.00\%), bread (100.00\%), mandarin oranges (100.00\%) and ham (100.00\%). The following foods were correctly assessed least often: banana (58.33\%), cereal flakes with chocolate (70.83\%) and vegetable stew (70.83\%). In the case of banana and cereal flakes with chocolate, participants assessed the portion size as two portions smaller than the real one.

A more detailed view into the participants' visual assessments was provided by the 12-point scale (Table 2). The following foods were correctly assessed most often: apple (66.67\%), curved bread rolls (kiflice) (62.50\%), chocolate (54.17\%), eggs (54.17\%), meat soup (54.17\%), mandarin oranges (54.17\%) and fluffy corn chips (flips) (54.17\%). The following foods were correctly assessed least often: banana (8.33\%), chocolate (12.50\%), vegetable soup (29.17\%), bread (29.17\%) and vegetable stew (29.17\%). Spearman coefficient for results on the 12-point scale ranged from 0.003 to 0.064 , indicating weak correlation. These results suggest that the participants were able to assess food portion sizes based on the photograph series.

Data were then analysed using the ANOVA $\omega^{2}$ test, and two types of $\omega^{2}$ were calculated: one for portion size (A-D) and
TABLE 1. Visual assessment of portion size on a 4-point scale based on a food photograph series, stratified by the number of points of difference between assessed and actual size

\begin{tabular}{|c|c|c|c|c|c|c|}
\hline \multirow[t]{2}{*}{ Food } & \multirow[t]{2}{*}{$\mathrm{n}$} & \multicolumn{5}{|c|}{$\begin{array}{l}\text { Percentage of participants whose } \\
\text { assessment of portion size differed } \\
\text { from the actual size by the indicated } \\
\text { no. of points }\end{array}$} \\
\hline & & 0 & -1 & 1 & $<-1$ & $>1$ \\
\hline Banana & 24 & 58.33 & 33.33 & 4.17 & 4.17 & 0.00 \\
\hline Chocolate & 24 & 100.00 & 0.00 & 0.00 & 0.00 & 0.00 \\
\hline $\begin{array}{l}\text { Cereal flakes with } \\
\text { chocolate }\end{array}$ & 24 & 70.83 & 8.33 & 16.67 & 0.00 & 4.17 \\
\hline Porridge & 24 & 91.67 & 8.33 & 0.00 & 0.00 & 0.00 \\
\hline Hot dogs & 24 & 91.67 & 8.33 & 0.00 & 0.00 & 0.00 \\
\hline Apple & 24 & 100.00 & 0.00 & 0.00 & 0.00 & 0.00 \\
\hline Eggs & 24 & 100.00 & 0.00 & 0.00 & 0.00 & 0.00 \\
\hline Plain yoghurt & 23 & 91.30 & 0.00 & 8.70 & 0.00 & 0.00 \\
\hline Fruit yoghurt & 24 & 95.83 & 0.00 & 4.17 & 0.00 & 0.00 \\
\hline Meat soup & 24 & 87.50 & 8.33 & 4.17 & 0.00 & 0.00 \\
\hline Vegetable soup & 24 & 87.50 & 8.33 & 4.17 & 0.00 & 0.00 \\
\hline Cookies & 24 & 91.67 & 8.33 & 0.00 & 0.00 & 0.00 \\
\hline Bread & 24 & 100.00 & 0,00 & 0.00 & 0.00 & 0.00 \\
\hline Mandarin oranges & 24 & 100.00 & 0,00 & 0.00 & 0.00 & 0.00 \\
\hline Crepes & 24 & 95.83 & 4.17 & 0.00 & 0.00 & 0.00 \\
\hline Curved bread rolls (kiflice) & 24 & 95.83 & 4.17 & 0.00 & 0.00 & 0.00 \\
\hline Fluffy corn chips (flips) & 24 & 87.50 & 0.00 & 12.50 & 0.00 & 0.00 \\
\hline Pretzel sticks & 24 & 95.83 & 0.00 & 4.17 & 0.00 & 0.00 \\
\hline Ham & 24 & 100.00 & 0.00 & 0.00 & 0.00 & 0.00 \\
\hline Vegetable stew & 24 & 70.83 & 8.33 & 20.83 & 0.00 & 0.00 \\
\hline Fruit salad & 23 & 82.61 & 8.70 & 8.70 & 0.00 & 0.00 \\
\hline
\end{tabular}

another for portion weight (Table 3). The results indicated that assessments based on grams overlapped with those based on photographs. The results in Table 3 indicate that participants tended to incorrectly assess portion sizes of banana $(29.3 \%)$, porridge (22.8\%), hot dogs (20.3\%) and plain yoghurt (19.1\%). Within the limits of statistical significance, the participants correctly assessed portion sizes of other foods.

More than $16 \%$ of participants said that it was difficult or quite difficult to assess portion sizes of banana, fruit salad cereal flakes with chocolate, fruit yoghurt, vegetable stew pretzel sticks and puffed corn chips (flips). This self-reporting indicated difficulty in assessing banana portions, consistent with the $w^{2}$ analysis, while it indicated good assessment ability for fruit salad, porridge, vegetable stew, pretzel sticks and puffed corn chips (flips). The participants further indicated that it was difficult for them to assess portion sizes of liquid and sliced food, which is consistent with the $w^{2}$ analysis in the case of banana and plain yoghurt. 
TABLE 2. Visual assessment of portion size on a 12-point scale based on a food photograph series, stratified by the number of points of difference between assessed and actual size

\begin{tabular}{|c|c|c|c|c|c|c|}
\hline \multirow[t]{2}{*}{ Food } & \multirow[t]{2}{*}{$\mathrm{n}$} & \multicolumn{5}{|c|}{$\begin{array}{l}\text { Percentage of participants whose } \\
\text { assessment of portion size differed } \\
\text { from the actual size by the indicated } \\
\text { no. of points }\end{array}$} \\
\hline & & 0 & -1 & 1 & $<-1$ & $>1$ \\
\hline Banana & 24 & 8.33 & 8.33 & 29.17 & 4.17 & 50.00 \\
\hline Chocolate & 24 & 54.17 & 8.33 & 37.50 & 0.00 & 0.00 \\
\hline $\begin{array}{l}\text { Cereal flakes with } \\
\text { chocolate }\end{array}$ & 24 & 12.50 & 25.00 & 12.50 & 33.33 & 16.67 \\
\hline Porridge & 24 & 33.33 & 8.33 & 33.33 & 0.00 & 25.00 \\
\hline Hot dogs & 24 & 45.83 & 4.17 & 29.17 & 0.00 & 20.83 \\
\hline Apple & 24 & 66.67 & 12.50 & 20.83 & 0.00 & 0.00 \\
\hline Eggs & 24 & 54.17 & 8.33 & 33.33 & 0.00 & 4.17 \\
\hline Plain yoghurt & 23 & 47.83 & 34.78 & 4.35 & 13.04 & 0.00 \\
\hline Fruit yoghurt & 24 & 45.83 & 41.67 & 8.33 & 4.17 & 0.00 \\
\hline Meat soup & 24 & 54.17 & 12.50 & 12.50 & 12.50 & 8.33 \\
\hline Vegetable soup & 24 & 29.17 & 16.67 & 37.50 & 4.17 & 12.50 \\
\hline Cookies & 24 & 45.83 & 16.67 & 16.67 & 0.00 & 20.83 \\
\hline Bread & 24 & 29.17 & 25.00 & 37.50 & 0.00 & 8.33 \\
\hline Mandarin oranges & 24 & 54.17 & 20.83 & 16.67 & 0.00 & 8.33 \\
\hline Crepes & 24 & 41.67 & 20.83 & 33.33 & 0.00 & 4.17 \\
\hline Curved bread rolls (kiflice) & 24 & 62.50 & 4.17 & 29.17 & 0.00 & 4.17 \\
\hline Fluffy corn chips (flips) & 24 & 54.17 & 8.33 & 20.83 & 16.67 & 0.00 \\
\hline Pretzel sticks & 24 & 50.00 & 12.50 & 16.67 & 8.33 & 12.50 \\
\hline Ham & 24 & 45.83 & 29.17 & 25.00 & 0.00 & 0.00 \\
\hline Vegetable stew & 24 & 29.17 & 20.83 & 8.33 & 29.17 & 12.50 \\
\hline Fruit salad & 23 & 39.13 & 8.70 & 30.43 & 8.70 & 13.04 \\
\hline
\end{tabular}

\section{DISCUSSION}

This work was based on photograph series of food and drink that were developed as national quantitative tools for assessing dietary consumption of children up to 9 years of age in Croatia and to determine the amounts and types of food that they consume most often. The portions displayed in each series of four photographs span the range from $5^{\text {th }}$ to $95^{\text {th }}$ percentile of the amounts of food consumed by children in Croatia, based on 3-day food diaries (7). The present study took the next step in the development and implementation of this dietary assessment tool by validating it in a nationally representative population, in accord with the recommendations of the European Food Safety Authority (5). The validation process can verify whether the photographs accurately express food amounts and can be used as a national tool for portion size determination in children.

The participants in this study were mothers of small children because mothers are most often responsible for the
TABLE 3. ANOVA $\omega^{2}$ evaluation of results based on photographs A-D and results based on portion weights

\begin{tabular}{|c|c|c|}
\hline Food & $\begin{array}{l}\omega^{2} \text { on responses } \\
\text { based on } \\
\text { photographs A-D }\end{array}$ & $\begin{array}{l}\omega^{2} \text { on responses } \\
\text { based on portion } \\
\text { weights }\end{array}$ \\
\hline Banana & 0.293 & 0.119 \\
\hline Chocolate & 0.081 & 0.000 \\
\hline Cereal flakes with chocolate & 0.000 & 0.039 \\
\hline Porridge & 0.228 & 0.032 \\
\hline Hot dogs & 0.203 & 0.201 \\
\hline Apple & 0.000 & 0.029 \\
\hline Eggs & 0.084 & 0.000 \\
\hline Plain yoghurt & 0.191 & 0.212 \\
\hline Fruit yoghurt & 0.129 & 0.168 \\
\hline Meat soup & 0.000 & 0.051 \\
\hline Vegetable soup & 0.044 & 0.031 \\
\hline Cookies & 0.069 & 0.000 \\
\hline Bread & 0.025 & 0.000 \\
\hline Mandarin oranges & 0.000 & 0.000 \\
\hline Crepes & 0.015 & 0.000 \\
\hline Curved bread rolls (kiflice) & 0.104 & 0.000 \\
\hline Fluffy corn chips (flips) & 0.006 & 0.077 \\
\hline Pretzel sticks & 0.000 & 0.000 \\
\hline Ham & 0.000 & 0.000 \\
\hline Vegetable stew & 0.021 & 0.050 \\
\hline Fruit salad & 0.021 & 0.000 \\
\hline
\end{tabular}

food that children consume, so they are the customary respondents in dietary assessment surveys about children. The participants in this study were homogeneous in their age, sex and education level, and all three factors can influence the ability to assess food portion sizes (8-11).

The protocol in our validation study was designed based on the validation of photograph series in the PANCAKE project (12). Similar studies for the purpose of developing countryspecific portion size measurement aids have been carried out in Italy, France, the United Kingdom, Finland, the United Arab Emirates, and other countries (10, 13-17).

The present validation showed that participants could accurately assess food size portions, similar to the results reported by Ovaskainen et al. (16), who found that small and intermediate portions were assessed more correctly than large portions. Our results overlap partially with those by Trolle et al. (18), who report that portions rated 3-4 were accurately assessed more often than the largest portions rated 6 .

In the 4-point scale in our study, portions that participants assessed as slightly larger (+) or smaller (-) than one of the four main categories (A-D) were recoded as the correspond- 
ing main category. This scale can give an overall sense of how well respondents assess food portion sizes, and other studies have applied a similar approach $(19,20)$. When using this scale, participants were worst at assessing portion sizes of banana, cereal flakes with chocolate, and vegetable stew. This may reflect the results of Lucas et al. (13), who found that participants were less accurate at assessing food served in pieces, since they tended to rely on the number of pieces, which would lead to inaccurate assessment in our study. Nelson et al. (21) found that participants often under- or overestimated amounts of some types of food such as potato purée or spaghetti, perhaps because the third dimension of depth is missing in the photographs. This may help explain why our participants were less accurate at assessing portion sizes of cereal flakes with chocolate and vegetable stew.

We also asked participants to assess food portion sizes using a 12-point scale, which took into account portion sizes intermediate between neighbouring photographs in the four-picture series. The foods for which portion sizes were assessed most accurately on both the 4- and 12-point scales were apple, chocolate, eggs and mandarin oranges; the worst-assessed foods on both scales were banana, cereal flakes with chocolate, and vegetable stew. The use of the 12-point scale allowed more detailed insights into how well participants assessed portion sizes: some foods, such as bread, were well-assessed according to the 4-point scale but among the worst-assessed foods according to the 12-point scale. In such cases, it may be that participants are inaccurate at assessing portion sizes, but this inaccuracy may remain undetected if a crude scale is used.

Spearman coefficients between actual portion sizes and those assessed by participants were lower in our study (0.003-0.064) than the coefficients of 0.73-0.92 reported by Trolle et al. (18). In our case, only a weak correlation was indicated. However, Spearman coefficient reflects only distance of the assessed portion sizes from the actual size and does not take into account the magnitude of the values on the scale. Given the relatively narrow scales used in this study, it may not be the most appropriate measure of correlation strength. Therefore, we also used the ANOVA $\omega^{2}$ test, which takes into account the values on the scale. This test identified banana (29.3\%), porridge (22.8\%), hot dogs (20.3\%) and plain yoghurt (19.1\%) as those for which our photograph series could not be validated as a portion size measurement aid. Lucas et al. (13) also observed errors ranging from small $(<10 \%)$ to moderate $(10 \%-25 \%)$ in their validation study.

Disadvantage of our study was the small number of participants. Another disadvantage was that we did not take into account food volume, which might have allowed us to apply the photographs to assessment of portion sizes of foods that were different from the ones depicted but had similar appearance and density, as shown by Trolle et al. (18). For example, measurement of the thickness of cereal flakes with chocolate could allow analysis of whether photographs of this food can also aid portion size assessment of breakfast cereals such as cornflakes or müsli.

A strength of our study was that we applied statistical methods not used by Trolle et al. (18). The use of a 12-point scale in our study allowed potentially more accurate assessment of which photograph series were effective aids, and the ANOVA $\omega^{2}$ test provided information not only about statistical differences but also about quantitative differences. This appears to be the first validation of portion size measurement aids for dietary assessment of children in Croatia. The results may be useful for food industry, such as for determining the serving sizes depicted on product packaging.

\section{CONCLUSION}

In this work, 17 out of 21 photograph series of foods were validated as portion size measurement aids in assessment of the amounts and types of foods consumed by young children in Croatia. The series that were not validated here depicted banana (0.293), porridge (0.228), hot dogs (0.203) and plain yoghurt (0.191). Participants were more accurate at assessing smaller portions. Further work is needed to determine why these foods were poorly assessed so that the photograph series can be modified accordingly.

\section{ACKNOWLEDGEMENTS}

This study was funded by the Croatian Food Agency. The authors would like to thank study participants for their voluntary participation in the study. The authors thank student volunteers who weighed food portions and served food to participants.

\section{REFERENCES}

1. EFSA NDA Panel (EFSA Panel on Dietetic Products, Nutrition and Allergies), 2013. Scientific Opinion on nutrient requirements and dietary intakes of infants and young children in the European Union. EFSA J. 2013;11:3408. doi: 10.2903/j.efsa.2013.3408

2. Bralić I, Jovančević $M$, Predavec $S$, Grgurić J. Pretilost djece: novo područje multidisciplinarnog preventivnog programa [Overweight in children: a new field for a multidisciplinary preventive program]. Paediatr Croat. 2010:54:25-34. (in Croatian)

3. Mamić $M$, Kučan P, Vukman D, Niseteo T. Učestalost malnutricije i energetski unos $u$ hospitalizirane djece [Frequency of malnutrition and energy intake in hospitalized children]. Paediatr Croat. 2018;62:74-80. (in Croatian) doi: 0.13112/PC.2018.10

4. Ocké $M$, Brants $H$, Dofkova $M$, et al. Feasibility of dietary assessment methods, other tools and procedures for a pan-European food consumption survey among infants, toddlers and children. Eur J Nutr. 2014;54:721-32. doi: 10.1007/s00394-014-0750-8 
5. European Food Safety Authority, 2014. Guidance on the EU Menu methodology. EFSA J. 2014;12:3944. doi: 10.2903/j.efsa.2014.3944

6. Lee RD, Nieman DC. Measuring diet. In: Lee RD, Nieman DC, editors. Nutritional Assessment, $5^{\text {th }}$ edn. New York, NY: McGraw-Hill, 2010; 68-88, 95-6.

7. Rumbak I, Kunić T, Niseteo T, Vukman D, Sokolić D, Colić Barić I. Veličina porcija hrane i pića u male djece [Portion sizes of food and drink in young children]. In: Šubarić D, Jašić M, editors. Proceedings of the $9^{\text {th }}$ International Scientific and Professional Conference With Food to Health. Osijek: Studio HS internet d.o.o., 2016; 1-11. [In Croatian]

8. Wein EE, Sabry JH, Evers FT. Recalled estimates of food portion size. J Can Diet Assoc. 1990;51:400-3.

9. Nelson M, Atkinson M, Darbyshire S. Food photography II: Use of food photographs for estimating portion size and the nutrient content of meals. Br J Nutr.1996;76:31-49.

10. Faggiano $F$, Vineis $P, C$ ravanzola $D$, et al. Validation of a method for the estimation of food portion size. Epidemiology. 1992;3:379-82.

11. Webb CA, Yuhas JA. Ability of WIC clientele to estimate food quantities. J Am Diet Assoc. 1988;88:601-2.

12. Ambrus Á, Horváth Z, Farka Z, et al. Pilot Study in the View of a PanEuropean Dietary Survey - Adolescents, Adults and Elderly, 2013. Available online: www.efsa.europa.eu/publications. Accessed 1 July 2016. doi: 10.2903/sp.efsa.2013.EN-508

13. Lucas F, Niravong M, Villeminot S, Kaaks R, Clavel-Chapelon F. Estimation of food portion size using photographs: validity, strenghts, weaknesses and recommendations. J Hum Nutr Diet. 1995;8:65-74.
14. Robson PJ, Livingstone MB. An evaluation of food photographs as a tool for quantifying food and nutrient intakes. Public Health Nutr. 2000;3:183-92

15. Frobisher C, Maxwel SM. The estimation of food portion sizes: a comparison between using descriptions of portion sizes and a photographic food atlas by children and adults. J Hum Nutr Diet. 2003;16:181-8.

16. Ovaskainen $\mathrm{ML}$, Paturi $\mathrm{M}$, Reinivuo $\mathrm{H}$, et al. Accuracy in the estimation of food servings against the portions in food photographs. Eur J Clin Nutr. 2008;62:674-81. doi: 10.1038/sj.ejcn.1602758

17. Ali HI, Platat C, El Mesmoudi N, El Sadig M, Tewfik I. Evaluation of a photographic food atlas as a tool for quantifying food portion size in the United Arab Emirates. PLoS One. 2018;13:e0196389. doi: 10.1371/journal. pone.0196389

18. Trolle E, Vandevijvere $S$, Ruprich J, et al. Validation of a food quantification picture book targeting children of 0-10 years of age for pan-European and national dietary surveys. Br J Nutr. 2013;110:2298-308. doi: 10.1017/ S0007114513001694

19. Nelson M, Haraldsdóttir J. Food photographs: practical guidelines 1. Design and analysis of studies to validate portion size estimates. Public Health Nutr. 1998;1:219-30.

20. Lillegaard ITL, Øverby NC, Andersen LF. Can children and adolescents use photographs of food to estimate portion sizes? Eur J Clin Nutr. 2005;59:6117. doi: 10.1038/sj.ejcn.1602119

21. Nelson M, Atkinson M, Darbyshire S. Food photographic 1: the perception of food portion size from photographs. Br J Nutr. 1994;72:649-63.

\title{
Vrednovanje niza fotografija kao pomoćnog alata za provođenje dijetetičkih metoda u djece
}

\author{
Ivana Rumbak, Darja Sokolić, Tena Blažok, Dragica Šakić, Diana Vukman, Tena Niseteo, Irena Colić Barić
}

Određivanje unosa hrane kod djece je zahtjevno i traži dijetetičke metode koje će biti prikladno specifične za opisivanje kao i za kvantificiranje unosa hrane. Niz fotografija može se upotrijebiti kako bi se ispitanicima pomoglo pokazati veličinu porcije hrane, ali te fotografije trebaju biti vrednovane na nacionalno reprezentativnom uzorku stanovništva. Cilj ovoga istraživanja bio je vrednovati niz fotografija kao pomoć u mjerenju veličine porcija tijekom prehrambene procjene djece u Hrvatskoj. Istraživanje je obuhvatilo 28 majki djece u dobi od 3 mjeseca do 10 godina koje su trebale odabrati jednu od četiri fotografije u nizu koja najbolje odgovara količini hrane koja im je poslužena. Od 21 ispitanog niza 17 ih je bilo primjereno za procjenu veličine porcija hrane. Sudionice su najlošije procijenile veličinu porcije banane (29,3\%), kaše (22,8\%), hrenovki u tijestu (20,3\%) i običnog jogurta (19,1\%). Potrebna su daljnja istraživanja kako bi se utvrdilo zbog čega se ove vrste hrane loše prepoznaju, kako bi se fotografije mogle poboljšati $i$ vrednovati. 